\title{
Is the digestive gland of Mytilus galloprovincialis a tissue of choice for estimating cadmium exposure by means of metallothioneins?
}

Biserka Raspor*, Zrinka Dragun, Marijana Erk, Dušica Ivanković and Jasenka Pavičić

Ruđer Bošković Institute, Center for Marine and Environmental Research, POBox 180, 10002 Zagreb, Croatia

* phone: xx385-1-4680216;

fax: $\quad$ xx385-1-4680242;

e-mail: raspor@rudjer.irb.hr

\section{Abstract}

A study performed over 12 months with caged mussels $\underline{M}$. galloprovincialis in the coastal marine zone which is under the urban pressure, reveales a temporal variation of digestive gland mass which causes "biological dilution" of cytosolic metallothionein (MT) and trace metal $(\mathrm{Cd}, \mathrm{Cu}, \mathrm{Zn}, \mathrm{Fe}, \mathrm{Mn})$ concentrations. The dilution effect was corrected by expressing the cytosolic MT and metal concentrations as the tissue content. Consequently, the changes of the average digestive gland mass coincide with the changes of MT and trace metal contents. In the period from February to June, MT contents are nearly twice and trace metal contents nearly three times higher than the remaining months. The period of increased average digestive gland mass, of MT and trace metal contents is probably overlapping with the sexual maturation of mussels (gametogenesis) and the enhanced food availability. Due to the fact that natural factors contribute more to the MT content than the sublethal levels of $\mathrm{Cd}$, digestive gland of $\underline{\mathrm{M}}$. galloprovincialis is not considered as a tissue of choice for estimating $\mathrm{Cd}$ exposure by means of MTs.

$\underline{\text { Key words: caged bivalves, Mytilus galloprovincialis; }}$; digestive gland mass variation; tissue content of metallothioneins and trace metals 
Introduction

Coastal seawater is often under the urban and industrial pressure due to metal inputs. Metals are persistent and some are bioaccumulated in marine organisms. Filter-feeding bivalves are abundant in coastal waters and thus often used for monitoring trace metal burden as the consequence of anthropogenic activities (Giusti et al., 1999). By means of specific, inducible proteins, such as metallothioneins (MTs), heavy metal homeostasis and detoxification in marine invertebrates occurs (Viarengo and Nott, 1993). Induction of MTs is regarded as a biochemical response to metal exposure, but biotic and abiotic factors additionally influence MT levels and have to be considered in the assessment of metal exposure (Langston et al., 1998). The MT response to metals is tissue specific. As main metabolic and storage tissue for metals, digestive gland of bivalves has high basal MT level, which probably reflects high tissue content of $\mathrm{Cu}$ and $\mathrm{Zn}$ (Geffard et al., 2001). Within the framework of the Mediterranean Action Plan (UNEP/MAP, 1999) digestive gland of Mytilus galloprovincialis has been selected as target tissue for survey of metal exposure by means of MTs as a specific biomarker. While controlled exposure experiments with Cd clearly indicate de novo synthesis of MT proteins in the digestive gland of mussels (Raspor et al., 1987; Bebianno and Langston, 1991), the field experiments with oysters do not clearly differentiate MT levels in the digestive gland at metal-rich and the control sites (Geffard et al., 2001).

The aim of our study was to conduct field experiment over one year with the defined stock of mussels $\underline{M}$. galloprovincialis, transplanted from an aquaculture area to 4 different sites in the part of the Adriatic Sea which is under urban pressure (Kaštela Bay, Eastern Adriatic Sea). Biochemical (MT) and chemical (metals) parameters were 
determined in the heat-treated cytosol of the composite sample of mussel digestive glands of caged organisms. The study is based on the same stock of mussels, of the same size, age and origin, which is the prerequisite to optimize resolution power of chemical stress at different locations (De Kock and Kramer, 1994). Such set-up enabled us to follow up temporal fluctuations of digestive gland mass and consequently cytosolic MT and metal levels with the purpose to clarify if the digestive gland of $\underline{\mathrm{M}}$. galloprovincialis is a tissue of choice for estimating cadmium exposure by means of MTs.

Materials and Methods

\section{Mussel caging and sampling}

Filter-feeding $\underline{\text { M. galloprovincialis }}$ of defined length $(5.1 \pm 0.2 \mathrm{~cm})$ and age $(12 \pm 1$ months) were transplanted from an aquaculture area and deployed at 4 different sites within Kaštela Bay (Fig. 1, sites A to D), a recipient of most of urban and industrial wastewater of the area. Deployment sites were selected taking into account the hydrographic, chemical and biological characteristics of the Bay (Kušpilić et al., 1991; Barić et al., 1992; Beg-Paklar and Gačić, 1997). Within the Bay prevailing anticlockwise circulation of water masses exists and their average retention time amounts to 30 days. According to numerous indicators, including primary production assessment, the Kaštela Bay could be categorized as a highly eutrophic area (Barić et al., 1992). At 200 to $500 \mathrm{~m}$ from the shore (site B) the average annual organic matter content in the suspended particles amounts to $10 \%$ (Tudor, 1993). In this shallow area seasonal variability of the suspended particles concentration and resuspension of sediment particles of high organic matter content $(>20 \%)$ contribute to the metal content uptake 
by the filter feeding organisms, like mussels. Mass partition of metals (expressed on dry mass basis) in the fine-grained fraction of the surface marine sediments within the studied area amounts to $100 \mathrm{mg} \mathrm{kg}^{-1}$ for $\mathrm{Zn}, 40 \mathrm{mg} \mathrm{kg}^{-1}$ for $\mathrm{Cu}$ and $0.4 \mathrm{mg} \mathrm{kg}^{-1}$ for $\mathrm{Cd}$ (Bogner et al., 1998). The decrease of $\mathrm{Zn}$ and $\mathrm{Cu}$ mass partition with sediment depth indicates to the anthropogenic sources of these metals.

At the deployment sites the water depth was $10 \mathrm{~m}$, while the distance from the shore varied from 50 to $400 \mathrm{~m}$. At each caging site eight net-like baskets (each one containing 50 specimens) were deployed $1.5 \mathrm{~m}$ above the sea bottom on September $15^{\text {th }}, 1997$; one basket was sampled at a time. Monthly sampling was performed in October, November and December 1997, to detect any changes which might reflect the acclimation of the Mediterranean mussels to new ambient conditions. In 1998 bimonthly sampling was performed (February, April, June, August). The last one took place in September 1998 to end up the round. Within current month, sampling took place on the same date as the deployment date. At stations A and B sampling was complete (8 times), while due to rough weather at site $\mathrm{C}$ one sampling and at site $\mathrm{D}$ two samplings were not accomplished. Therefore, data at these two locations in particular periods are missing.

After sampling, mussels were kept for 24 hours in the filtered $(0.45 \mu \mathrm{m})$ seawater to depurate the gut content (Bordin et al., 1992; Odžak et al., 2001), and than transported to the Laboratory in Zagreb, where biometry and tissue dissection took place. Composite samples of mussel tissues were deep frozen at $-80^{\circ} \mathrm{C}$ until further processing and analysis.

\section{Mussel biometry}


At each caging site and sampling period the composite sample of the digestive glands was made up on average from 28 specimens. Therefore, no replicates per sampling period and site exist, but results represent the average biochemical and chemical responses. Average digestive gland mass within composite tissue sample was determined in order to observe temporal fluctuations of that tissue, mainly related to reproductive cycle and food availability (Bordin et al., 1997). At the beginning of our field study the mussels' age was defined as $12 \pm 1$ months. Shell mass was selected as additional indicator of age, due to the fact that the calcareous shell continues to be formed even when the length increments are not observed (Fischer, 1983). Our observations confirm that during 12 months of caging, mussels' length increased on average from 5.2 to $5.9 \mathrm{~cm}$, while the shell mass increased on average from 4.5 to $7.0 \mathrm{~g}$.

\section{$\underline{\text { Homogenate and cytosolic fraction }}$}

Composite digestive gland tissue was homogenized in three volumes of $0.02 \mathrm{M}$ TRIS$\mathrm{HCl}$ buffer, $\mathrm{pH}=8.6$, containing leupeptine $(0.006 \mathrm{mM})$, phenylmethylsulphonylfluoride (PMSF, $0.5 \mathrm{mM}$ ) and 2-mercaptoethanol $(0.01 \%)$, on an ice-bath with a Potter-Elvehjem type of homogenizer. The homogenate was centrifuged in the Sorval RC28S centrifuge by $\mathrm{Du}$ Pont at $30000 \times \mathrm{xg}$ for 40 minutes at $4^{\circ} \mathrm{C}$. The isolated supernatant (S30) contained total cytosolic proteins (Yang et al., 1995). Further on, S30 was heat-treated at $70^{\circ} \mathrm{C}$ for 10 minutes using The Dri Block (Techne), and subsequently centrifuged at $30000 \mathrm{xg}$ for 20 minutes at $4^{\circ} \mathrm{C}$. This supernatant contained MTs as heat-stable cytosolic proteins (Yang et al., 1995). 


\section{Cytosolic MT concentration}

MT concentration in the heat-treated supernatant $\left(\mathrm{mg} \mathrm{ml} \mathrm{ml}^{-1}\right)$ was determined by electrochemical method in a differential pulse mode (Raspor et al., 2001), on a Metrohm 290E hanging mercury drop electrode (HMDE). MT calibration straight line was obtained at $7^{\circ} \mathrm{C}$ with the commercial rabbit liver MT(I+II) from Sigma.

\section{$\underline{\text { Heat-denatured cytosolic trace metal concentrations }}$}

Metal concentrations in the heat-treated S30 fraction $\left(\mu \mathrm{g} \mathrm{ml}{ }^{-1}\right)$ were determined by means of Varian double beam flame atomic absorption spectrometer (SpectrAA 220) with multielement lamps and a deuterium lamp for baseline correction. Atomization of metals was achieved in the air-acetylene flame. Calibration was performed using Merck's standard solutions of $\mathrm{Cd}, \mathrm{Zn}, \mathrm{Cu}, \mathrm{Mn}$ and $\mathrm{Fe}$. Selected concentration ranges of Cd 0.01-0.05 $\mu \mathrm{g} \mathrm{ml}^{-1}$; Zn 0.5-2.0 $\mu \mathrm{g} \mathrm{ml}^{-1}$; $\mathrm{Cu}$ 0.1-0.5 $\mu \mathrm{g} \mathrm{ml}^{-1}$; Mn 0.05-0.5 $\mu \mathrm{g} \mathrm{ml}^{-1}$; and Fe $0.1-0.5 \mu \mathrm{g} \mathrm{ml}^{-1}$ for the construction of the calibration straight lines were prepared in Tris-HCl buffer $(0.004 \mathrm{M})$ of the same concentration as the samples, which were prior to metal analysis fivefold diluted with redestilled water. Detection limits of the selected metals were as follows: $\mathrm{Cd} 0.003 \mu \mathrm{g} \mathrm{ml}^{-1}$; $\mathrm{Zn} 0.012 \mu \mathrm{g} \mathrm{ml}^{-1}$; $\mathrm{Cu} 0.002 \mu \mathrm{g} \mathrm{ml}^{-1}$; Mn $0.002 \mu \mathrm{g} \mathrm{ml}^{-1}$; and Fe $0.009 \mu \mathrm{g} \mathrm{ml}^{-1}$.

\section{$\underline{\text { Statistical treatment of results }}$}

All statistical analyses (Kruskal-Wallis test, multiple regression analysis, two-way ANOVA) were performed in SigmaStat for Windows Version 1.0, except the principal component analysis (PCA), which was performed in SPSS 10.0 for Windows.

Results and Discussion 
MTs, as water-soluble proteins, are present in the cytosol, which is isolated from the composite sample of mussel digestive glands, and purified by heat-treatment. Metal concentrations were also determined in the heat-treated cytosolic fraction, in order to observe the relationship between MTs and metals, particularly $\mathrm{Cd}, \mathrm{Zn}$ and $\mathrm{Cu}$, which are known inducers of MT synthesis (Langston et al., 1998). Fe and Mn were considered as metals essential for mussels' metabolism. At all 4 sites, the highest metal concentrations present in the heat-treated digestive gland cytosol were those of $\mathrm{Zn}$ and Fe with median values of 1 to $2 \mu \mathrm{g} \mathrm{ml}^{-1}$, followed by $\mathrm{Cu} \approx 0.5 \mu \mathrm{g} \mathrm{ml}^{-1}, \mathrm{Mn} \approx 0.2 \mu \mathrm{g} \mathrm{ml}^{-}$ ${ }^{1}$, and $\mathrm{Cd} \approx 0.1 \mu \mathrm{g} \mathrm{ml}^{-1}$. Median value of MT concentration was $\approx 0.6 \mathrm{mg} \mathrm{ml}^{-1}$ (Table 1 ). The range of values presented in Table 1 comprises the caging period of 12 months.

$\underline{\text { Temporal variations of digestive gland mass, cytosolic MT and metal concentrations }}$ Variation of average mussel digestive gland mass over one year, at each caging site is presented in Fig. 2. Common is the fact that at 4 caging sites the average digestive gland mass of mussels reached the maximum in April 1998, when the concentration of MTs was minimal, while the peaks of MT concentration were observed in December 1997 and June 1998 (Fig. 3). Temporal variation of digestive gland mass is under influence of food availability and reproductive cycle. Since gonadic tissue penetrates into the digestive gland (Regoli and Orlando, 1993), two tissues cannot be separated by dissection (Regoli and Orlando, 1994). Lower concentrations of trace metals in the gonadic tissues (George and Coombs, 1977; La Touche and Mix 1982; Lobel and Wright, 1982) cause "biological dilution" of trace metal concentrations in the digestive gland. As already stated by Bordin et al. (1997), Amiard-Triquet et al. (1998) and Mouneyrac et al. (1998; 2000), variation of soft tissue mass also influences MT 
concentration in bivalves. The "biological dilution" is, thus, a valid explanation for the MT concentration in the digestive gland, too. Kruskal-Wallis test of MT and trace metal concentrations at 4 caging sites shows that differences between selected sites within Kaštela Bay are not statistically significant. Cytosolic concentrations of biochemical and chemical parameters determined in the digestive gland of caged mussels are comparable, leading to the conclusion that living conditions (biotic and abiotic) for mussels are comparable, too. The dependence of MT concentration on the combination of the following independent variables: trace metal concentrations $(\mathrm{Cd}, \mathrm{Cu}, \mathrm{Zn}, \mathrm{Mn}$, Fe), digestive gland mass and the shell mass, was analyzed by multiple linear regression. For that purpose, the results at 4 caging sites were treated as the same population of data. The obtained model explains $\sim 69 \%$ of MT concentration variability (Table 2), where $\mathrm{Cu}$ concentration has positive statistically significant influence $(\mathrm{p}<0.001)$, while $\mathrm{Fe}$ concentration and the digestive gland mass have negative statistically significant influence on MTs $(\mathrm{p}<0.001, \mathrm{p}<0.01$, respectively). The results of multiple regression analysis, thus, confirm that an increase of average digestive gland mass (Fig. 2) causes MT dilution in that organ, as already observed in Fig. 3. High positive correlation with $\mathrm{Cu}$ concentration reflects $\mathrm{MT}$ role in the $\mathrm{Cu}$ metabolism, as stated by Langston et al. (1998).

\section{MT and trace metal content of the digestive gland}

To counteract the effect of "biological dilution", cytosolic MT and metal concentrations were expressed as mass partition (multiplying their cytosolic concentration with factor of 4 , which corresponds to the homogenate dilution) and than corrected for the average digestive gland mass; in that manner MT and metal tissue content was calculated. The variation of MT and trace metal contents in the digestive gland of mussels, caged over 
12 months at 4 sites within Kaštela Bay, is shown in Fig. 4, a to f. It should be noticed that the maximal values of MT and metal contents were recorded in the period from February to June 1998. Exceptions were station C with high MT content in December 1997, and station B with high Zn content in August 1998, which could be related to somewhat higher digestive gland mass recorded at these two caging sites in the observed period.

Two-way analysis of variance showed statistically significantly higher $(\mathrm{p}<0.0001)$ MT and trace metal contents in the period from February to June, compared to the remaining months. In that period, MT contents are nearly two times, and trace metal contents nearly three times higher than during the remaining months. It can be hypothesized that the period of higher MT and metal contents is overlapping with the gonad development and the increased food availability. In the Mediterranean Sea, seasonal hydrological regime varies from winter mixing (January-February) to thermal stratification in summer and fall, causing nutrient depletion in the surface layer during summer, and reinjection to the surface layer during winter mixing (Marty et al, 2002). The same process was observed in the southern Adriatic Sea, where the supply of inorganic nutrients to the upper layer is followed by increased primary production and downward fluxes of particulate matter in early spring (Boldrin et al., 2002). The abundance of food may affect feeding rates and rates of water transport across the gills of filter-feeding organisms, thereby affecting the uptake of metals from both solution and food (Janssen and Scholz, 1979). Free metal ion concentration is the key metal form for its uptake from the solution, while high concentration of metals in food suggests it is an important source of metals, too (Luoma, 1983). Among trace metals, Fe and $\mathrm{Mn}$ are predominantly associated with the particles, while significant proportion of $\mathrm{Cd}$ is 
present in the dissolved state (Phillips and Rainbow, 1993). Exposure to soluble metals results primarily in their accumulation in the tissues like mantle and gills of the mollusks (Amiard, 1978), while metal intake via food results in metal compartmentalization in storage tissue of glandular type, like the digestive gland (Tenore et al., 1968; Viarengo and Nott, 1993). In digestive gland, phytoplankton ingestion is, thus, an important source of metals, because primary producers show some of the highest levels of metal accumulation in food chains (Sanders and Riedel, 1998). As a result of high food availability the contents of metals increase, but simultaneous development of gonads, possibly also stimulated by favourable environmental conditions, and their penetration into the digestive gland tissue causes the dilution of MT and trace metal concentrations. If MTs and trace metals are expressed as tissue content, the simultaneous increase with the average digestive gland mass occurs (Fig. 4, a to f).

\section{Principal component analysis (PCA)}

According to PC analysis, 2 components control overall $86 \%$ of parameters variability (Table 3), the first component $63 \%$ and the second one $23 \%$. The first component associates the following parameters, displaying correlation coefficients higher than 0.80: trace metal contents $(\mathrm{Zn}, \mathrm{Cu}, \mathrm{Fe}, \mathrm{Mn}), \mathrm{MT}$ content and the digestive gland mass. In the period from February to June, as seen on Fig. 4, simultaneous increase of the content of MTs and analyzed trace metals in the digestive gland of mussels has been observed, as well as the increase of digestive gland mass (Fig. 2), which is in accordance with the role of mussel digestive gland as a tissue for intracellular and extracellular digestion and storage of nutrients (Bayne et al., 1976). The abundance of food during that time of year enables the accumulation of the substances needed for 
gonad development (like glycogen, lipids and proteins), thereby stimulating the process of gametogenesis. Glycogen constitutes the dominant energy reserve fueling gametogenesis. When the stored glycogen, lipids and proteins are exhausted, gametogenesis may be fueled directly by circulating metabolites originating from the transformation of ingested food (De Zwaan and Mathieu, 1992). Due to intensified food supply, increased uptake of metals, some of which are known as MT inducers, also occurs. However, increased levels of metals that are observed in the period from February to June do not have to result in additional induction of MT synthesis, because, compared to the other tissues, MT level in the digestive gland of mussels is already high, especially during the periods of intense food uptake. As a result of high basal physiological pool of MTs, presence of free binding sites on MT molecules can be presumed. After saturating free $\mathrm{SH}$-sites, metals, like $\mathrm{Cd}$ and $\mathrm{Cu}(\mathrm{I})$ ions, which have higher stability constants of thiolate clusters, are able to displace $\mathrm{Zn}$ ions from a basal MT pool (Viarengo et al., 1985). The first component obtained by PCA, thereby, associates simultaneous abundance of food and gonad development with the higher digestive gland mass, MT and metal contents of mussels caged within Kaštela Bay. Cytosolic metal content of the digestive gland is therefore related to "trophically available metal" (Wallace and Luoma, 2003). Cadmium has the lowest correlation coefficient (0.62) with the first component. It is not surprising, since previous findings indicate that $\mathrm{Cd}$ accumulation is highly related to its concentration in seawater (Zaroogian, 1980; Cossa, 1988). Food is less important source of Cd to marine invertebrates (Kerfoot and Jacobs, 1976).

The second component associates the following parameters: shell mass, digestive gland mass and the contents of $\mathrm{Cd}, \mathrm{Zn}$ and MTs. Due to the strong correlation with the shell 
mass (0.94), the second component is associated with aging process of caged mussels. Our results confirm the statement by Fischer (1983), that calcareous shell continues to be formed even when the length increments are not observed. During 12 months of caging, calcareous shell mass increased on average from 4.5 to $7.0 \mathrm{~g}$ (Fig. 5), while the average length increased only $0.7 \mathrm{~cm}$. Important is to point out the relationship between the aging process and the increased $\mathrm{Cd}$ content (correlation coefficient 0.62 ), indication of $\mathrm{Cd}$ accumulation in the digestive gland of mussels caged in the coastal zone which is under the urban pressure. Within "aging component" somewhat lower correlation coefficients were obtained for Zn and MT contents ( 0.47 and 0.28 , respectively). The digestive gland contents of $\mathrm{Cu}, \mathrm{Fe}$ and $\mathrm{Mn}$ are not associated with the mussels' age, but are "trophically available metals". The increase of both $\mathrm{Cd}$ and $\mathrm{Zn}$ contents with mussels' age in the cytosol of digestive gland is consistent with the known affinity of these metals for MTs. Since the caged mussels were transplanted from the same aquaculture site to 4 different sites within Kaštela Bay, Cd levels measured in October 1997 were practically identical at all 4 sites (Fig. 4b). With the time elapsed, the differences in the $\mathrm{Cd}$ content in the digestive gland of mussels caged at 4 sites became evident (Fig. 4b), probably due to different bioavailability of $\mathrm{Cd}$ at different sites. The differences are specifically well observed in June 1998, when the Cd content is at the maximum, and decreases along the caging sites as follows: $A>C>B \cong D$. The highest $C d$ content at site A can be explained by the fact that site $\mathrm{A}$ is flashed with the incoming water masses from the Split channel, where the urban run-off water is discharged via mixed sewer system into the Split harbour (Bogner et al., 1998). Although time-related accumulation of $\mathrm{Cd}$, as toxic metal, occurs differently at 4 caging sites, these differences are not reflected in the level of MTs (Fig. 4a). The conclusion is that $\mathrm{Cd}$ in the digestive gland of mussels has not reached the level at which it could induce additional MT 
synthesis, because the basal physiological pool of MTs in the digestive gland is already high and is related to high tissue content of essential metals, $\mathrm{Zn}$ and $\mathrm{Cu}$ (Geffard et al., 2001). The existing level of MTs is, thus, sufficient to detoxify the levels of cytosolic metals $(\mathrm{Cd}, \mathrm{Cu}, \mathrm{Zn})$ reported in this study, without the need for additional induction. Similar observation was previously reported for digestive gland of Littorina littorea and

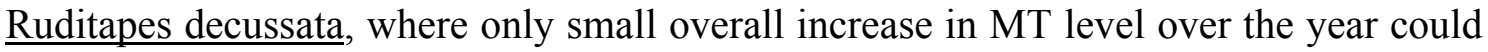
be detected, in spite of relatively high $\mathrm{Cd}$ influx, because $\mathrm{Cd}$ was sequestered by high levels of MTs inherent to that tissue, probably in relation to storage and turnover of essential metals (Bebianno et al., 1992; Bebianno et al., 1993). Geffard et al. (2001) came to similar conclusion for $\underline{\text { Crassostrea gigas, }}$ emphasizing that the digestive gland of this oyster has limited value as a tissue for biomonitoring through the measurement of MTs as a biomarker. The low level of significant de novo MT synthesis, as was suggested by Bebianno et al. (1993) for R. decussata, renders digestive gland unsuitable for detecting responses to sublethal level of $\mathrm{Cd}$ in the case of Mytilus galloprovincialis, too.

Concluding remarks

Digestive gland of mussels Mytilus galloprovincialis is often selected as a target tissue for the analysis of MTs as a biomarker of metal exposure. For environmental survey, of special interest is to resolve the effect of toxic metal $\mathrm{Cd}$ by means of MT level. Digestive gland, as a storage organ for nutrients, has the highest total protein content, compared to other mussel tissues, and consequently the highest content of a specific metal-binding proteins (MTs). Although, time-related accumulation of toxic metal Cd occurs differently at 4 caging sites within the survey area, these differences are not 
reflected in the MT level. Since basal MT pool in the digestive gland of $M$. galloprovincialis is high, related to the high cytosolic contents of $\mathrm{Cu}$ and $\mathrm{Zn}$, cadmium content has not reached the level which might induce additional MT synthesis. Inspite of high metal accumulation in the digestive gland, this organ does not meet the criteria as a tissue of choice for estimating the exposure of $M$. galloprovincialis to sublethal levels of $\mathrm{Cd}$. The physiological changes caused by gonadal development and food abundance contribute more to the changes in MT level than the bioavailable Cd concentrations.

Acknowledgements

Ministry of Science and Technology, Republic of Croatia, is acknowledged for the financial support of the research project 0098130 "Metals and cellular biomarkers". Additional acknowledgement to Dr. N. Odžak for deployment of mussels and to Dr. M. Erk for mussel sampling and transport to Zagreb. 
References

Amiard JC. ${ }^{110 \mathrm{~m}}$ Silver contamination mechanisms in a marine benthic food chain. 4. Effects of contamination mechanisms on radionuclide elimination. J. Exp. Mar. Biol. Ecol. 1978; 34: 215-225.

Amiard-Triquet C, Rainglet F, Larroux C, Regoli F, Hummel H. Metallothioneins in Arctic bivalves. Ecotoxicol. Environ. Saf. 1998; 41: 96-102.

Barić A, Marasović I, Gačić M. Eutrophication phenomenon with special reference to the Kaštela Bay. Chem. Ecol. 1992; 6: 51-68.

Bayne BL, Thompson RJ, Widdows J. Physiology: I. In: Bayne BL, editor, Marine mussels: their ecology and physiology, Cambridge University Press, Cambridge, 1976, pp. 121-206.

Bebianno MJ, Langston WJ. Metallothionein induction in Mytilus edulis exposed to cadmium. Mar. Biol. 1991; 108: 91-96.

Bebianno MJ, Langston WJ, Simkiss K. Metallothionein induction in Littorina littorea (Mollusca: Prosobranchia) on exposure to cadmium. J. Mar. Biol. Assoc. UK 1992; 72: 329-342.

Bebianno MJ, Nott JA, Langston WJ. Cadmium metabolism in the clam $\underline{\text { Ruditapes }}$ decussata: the role of metallothioneins. Aquat. Toxicol. 1993; 27: 315-334.

Beg-Paklar G, Gačić M. The wind effect on the Kaštela Bay current field. Acta Adriatica 1997; 38:31-43.

Bogner D, Juračić M, Odžak N, Barić A. Trace metals in fine-grained sediments of the Kaštela Bay, Adriatic Sea. Wat. Sci. Technol. 1998; 38:169-175. 
Boldrin A, Miserocchi S, Rabitti S, Turchetto MM, Balboni V, Socal G. Particulate matter in the southern Adriatic and Ionian Sea: characterisation and downward fluxes. J. Mar. Syst. 2002; 33: 389-410.

Bordin G, McCourt J, Rodriguez AR. Trace metals in the marine bivalve Macoma baltica in the Westerschelde Estuary (The Netherlands). Part 1: Analysis of total copper, cadmium, zinc and iron concentrations-Locational and seasonal variations. Sci. Total Environ. 1992; 127: 255-280.

Bordin G, McCourt J, Cordeiro-Raposo F, Rodriguez AR. Metallothionein-like metalloproteins in the baltic clam Macoma balthica: seasonal variations and induction upon metal exposure. Mar. Biol. 1997; 129: 453-463.

Cossa D. Cadmium in Mytilus spp: worldwide survey and relationship between seawater and mussel content. Mar. Environ. Res. 1988; 26: 265-284.

De Kock WC, Kramer KJM. Active biomonitoring (ABM) by translocation of bivalves molluscs. In: Kramer KJM, editor, Biomonitoring of coastal waters and estuaries, CRC Press, Boca Raton, 1994, pp. 51-84.

De Zwaan A, Mathieu M. Cellular biochemistry and endocrinology. In: Gosling E, editor, The mussel Mytilus: Ecology, physiology, genetics and culture, Elsevier Science Publishers B.V., Amsterdam, 1992, pp. 223-307.

Fischer H. Shell Weight as an independent variable in relation to cadmium content of molluscs. Mar. Ecol. Prog. Ser. 1983; 12: 59-75.

Geffard A, Amiard-Triquet C, Amiard JC, Mouneyrac C. Temporal variations of metallothionein and metal concentrations in the digestive gland of oysters (Crassostrea gigas) from a clean and a metal-rich site. Biomarkers 2001; 6: 91107. 
George SG, Coombs TL. The effects of chelating agents on the uptake and accumulation of cadmium by Mytilus edulis. Mar. Biol. 1977; 39: 261-268.

Giusti L, Williamson AC, Mistry A. Biologically available trace metals in Mytilus edulis from the coast of Northeast England. Environ. Int. 1999; 25: 969-981.

Janssen HH, Scholz N. Uptake and cellular distribution of cadmium in Mytilus edulis. Mar. Biol. 1979; 55: 133-141.

Kerfoot WB, Jacobs SA. Cadmium accrual in combined wastewater treatmentaquaculture system. Environ. Sci. Technol. 1976; 10: 662-667.

Kušpilić G, Marasović I, Vukadin I, Odžak N, Stojanoski L. Hydrographic conditions and nutrient requirements during red tide in the Kaštela Bay (middle Adriatic). Acta Adriatica 1991; 32:813-826.

Langston WJ, Bebianno MJ, Burt GR. Metal handling strategies in molluscs. In: Langston WJ, Bebianno MJ, editors, Metal metabolism in aquatic environments, Chapman \& Hall, London, 1998, pp. 219-283.

La Touche YD, Mix MC. Seasonal variation of arsenic and other trace elements in bay

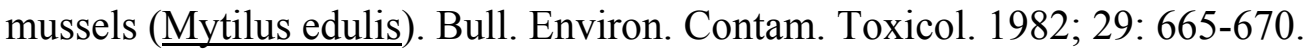

Lobel PB, Wright DA. Gonadal and nongonadal zinc concentrations in mussels. Mar. Pollut. Bull. 1982; 13: 320-323.

Luoma SN. Bioavailability of trace metals to aquatic organisms - a review. Sci. Total Environ. 1983; 28: 1-22.

Marty JC, Chiaverini J, Pizay MD, Avril B. Seasonal and interannual dynamics of nutrients and phytoplankton pigments in the western Mediterranean Sea at the DYFAMED time-series station (1991-1999). Deep-Sea Res. (II Top. Stud. Oceanogr.) 2002; 49: 1965-1985. 
Mouneyrac C, Amiard JC, Amiard-Triquet C. Effects of natural factors (salinity and body weight) on cadmium, copper, zinc and metallothionein-like protein levels in resident populations of oysters Crassostrea gigas from a polluted estuary. Mar. Ecol. Prog. Ser. 1998; 162: 125-135.

Mouneyrac C, Geffard A, Amiard JC, Amiard-Triquet C. Metallothionein-like proteins in Macoma balthica: effects of metal exposure and natural factors. Can. J. Fish. Aquat. Sci. 2000; 57: 34-42.

Odžak N, Zvonarić T, Kljaković-Gašpić Z, Barić A. Biomonitoring of copper, cadmium, lead, zinc and chromium in the Kaštela Bay using transplanted mussels. Fres. Environ. Bull. 2001;10: 37-41.

Phillips DJH, Rainbow PS. Biomonitoring of trace aquatic contaminants, Elsevier Science Publishers Ltd, London, 1993.

Raspor B, Pavičić J, Branica M. Possible biological reference material for environment control analyses - cadmium induced proteins from Mytilus galloprovincialis. Fresenius Z. Anal. Chem. 1987; 326: 719-722.

Raspor B, Paić M, Erk M. Analysis of metallothioneins by the modified Brdička procedure. Talanta 2001; 55: 109-115.

Regoli F, Orlando E. Mytilus galloprovincialis as a bioindicator of lead pollution: biological variables and cellular responses. Sci. Total Environ. 1993; Suppl (2): 1283-1292.

Regoli F, Orlando E. Seasonal variation of trace metal concentrations in the digestive gland of the Mediterranean mussel Mytilis galloprovincialis - comparison between a polluted and a non-polluted site. Arch. Environ. Contam. Toxicol. 1994; 27: 36-43. 
Sanders JG, Riedel GF. Metal accumulation and impacts in phytoplankton. In: Langston WJ, Bebianno MJ, editors, Metal metabolism in aquatic environments, Chapman \& Hall, London, 1998, pp. 59-76.

Tenore KR, Horton DE, Duke TW. Effects of bottom substrate on the brackish water bivalve Rangia cuneata. Chesapeake Sci. 1968; 9: 238-248.

Tudor M, Distribution and residence time of mercury in seawater and sediments of the Kaštela Bay. Ph. D. Thesis 1993, Faculty of Natural Sciences, University of Zagreb, Zagreb (in Croatian),

UNEP/MAP. MED POL Phase III, Programme for the assessment and control of pollution in the Mediterranean region. MAP Tech. Rep. Ser. No. 120, UNEP, Athens, 1999.

Viarengo A, Nott JA. Mechanisms of heavy metal cation homeostasis in marine invertebrates. Comp. Biochem. Physiol., C 1993; 104: 355-372.

Viarengo A, Palmero S, Zanicchi G, Capelli R, Vaissiere R, Orunesu M. Role of metallothioneins in $\mathrm{Cu}$ and $\mathrm{Cd}$ acumulation and elimination in the gill and digestive gland cells of Mytilus galloprovincialis Lam. Mar. Environ. Res. 1985; 16: $23-36$.

Wallace WG, Luoma SN. Subcellular compartmentalization of $\mathrm{Cd}$ and $\mathrm{Zn}$ in two bivalves. II. Significance of trophically available metal (TAM). Mar. Ecol. Prog. Ser. 2003; 257: 125-137.

Yang MS, Chiu ST, Wong MH. Uptake, depuration and subcellular distribution of cadmium in various tissues of Perna viridis. Biomed. Environ. Sci. 1995; 8: 176185.

Zaroogian GE. Crassostrea virginica as an indicator of cadmium pollution. Mar. Biol. 1980; 58: 275-284. 
Table 1. The median and the concentration ranges of MTs, $\mathrm{Cd}, \mathrm{Zn}, \mathrm{Cu}, \mathrm{Mn}$ and $\mathrm{Fe}$ in the heat-treated cytosol (S30) of the composite sample of digestive glands of Mytilus galloprovincialis Lmk., caged over 12 months at 4 sites (Fig. 1) within Kaštela Bay. Concentration ranges comprise the whole caging period of 12 months.

\begin{tabular}{|c|c|c|c|c|c|c|}
\hline & $\frac{\text { MTs }}{\mathrm{mg} \mathrm{ml}^{-1}}$ & $\frac{\mathrm{Cd}}{\mu \mathrm{g} \mathrm{ml}^{-1}}$ & $\begin{array}{c}\underline{\mathrm{Zn}} \\
\mu \mathrm{g} \mathrm{ml}^{-1}\end{array}$ & $\frac{\mathrm{Cu}}{\mu \mathrm{g} \mathrm{ml}^{-1}}$ & $\begin{array}{c}\underline{\mathrm{Mn}} \\
\mu \mathrm{g} \mathrm{ml}^{-1}\end{array}$ & $\begin{array}{c}\underline{\text { Fe }} \\
\mu \mathrm{g} \mathrm{ml}^{-1}\end{array}$ \\
\hline $\begin{array}{l}\text { Caging } \\
\text { site }\end{array}$ & $\begin{array}{c}\text { Median } \\
\text { Min-Max }\end{array}$ & $\begin{array}{c}\text { Median } \\
\text { Min-Max }\end{array}$ & $\begin{array}{c}\text { Median } \\
\text { Min-Max }\end{array}$ & $\begin{array}{c}\text { Median } \\
\text { Min-Max }\end{array}$ & $\begin{array}{c}\text { Median } \\
\text { Min-Max }\end{array}$ & $\begin{array}{c}\text { Median } \\
\text { Min-Max }\end{array}$ \\
\hline A & $\begin{array}{c}0.677 \\
0.525-0.865\end{array}$ & $\begin{array}{c}0.138 \\
0.084-0.205\end{array}$ & $\begin{array}{c}1.761 \\
1.355-2.366\end{array}$ & $\begin{array}{c}0.508 \\
0.374-0.621\end{array}$ & $\begin{array}{c}0.243 \\
0.171-0.365\end{array}$ & $\begin{array}{c}1.373 \\
1.235-1.853\end{array}$ \\
\hline B & $\begin{array}{c}0.656 \\
0.511-0.817\end{array}$ & $\begin{array}{c}0.100 \\
0.079-0.120\end{array}$ & $\begin{array}{c}1.879 \\
1.273-2.245\end{array}$ & $\begin{array}{c}0.516 \\
0.464-0.653\end{array}$ & $\begin{array}{c}0.268 \\
0.205-0.400\end{array}$ & $\begin{array}{c}1.381 \\
1.116-1.869\end{array}$ \\
\hline C & $\begin{array}{c}0.637 \\
0.547-0.812\end{array}$ & $\begin{array}{c}0.123 \\
0.093-0.165\end{array}$ & $\begin{array}{c}2.070 \\
1.245-2.232\end{array}$ & $\begin{array}{c}0.532 \\
0.457-0.766\end{array}$ & $\begin{array}{c}0.227 \\
0.208-0.397\end{array}$ & $\begin{array}{c}1.520 \\
1.148-2.161\end{array}$ \\
\hline D & $\begin{array}{c}0.645 \\
0.524-0.754\end{array}$ & $\begin{array}{c}0.122 \\
0.094-0.134\end{array}$ & $\begin{array}{c}2.154 \\
1.313-2.583\end{array}$ & $\begin{array}{c}0.587 \\
0.363-0.786\end{array}$ & $\begin{array}{c}0.218 \\
0.173-0.415\end{array}$ & $\begin{array}{c}1.377 \\
1.045-1.988\end{array}$ \\
\hline
\end{tabular}


Table 2. Multiple linear regression analysis:

Dependence of the heat-treated cytosolic MT concentration on the following independent variables: cytosolic trace metal concentrations, digestive gland mass and the shell mass

$$
\left(\mathrm{R}^{2}=0.69\right)
$$

\begin{tabular}{|ccc|}
\hline Variable & Coefficient & p \\
\hline Constant & 0.89 & $<0.0001$ \\
\hline Cd & 0.68 & 0.1464 \\
\hline Zn & -0.06 & 0.2164 \\
\hline Cu & 0.84 & $0.0006^{*}$ \\
\hline Mn & 0.26 & 0.2068 \\
\hline Fe & -0.25 & $0.0008^{*}$ \\
\hline $\begin{array}{c}\text { Digestive } \\
\text { gland mass }\end{array}$ & -0.59 & $0.0089^{*}$ \\
\hline Shell mass & -0.03 & 0.1089 \\
\hline
\end{tabular}

* statistically significant dependence 
Table 3. Parameters variability (trace metal and MT contents, digestive gland and shell mass) resolved in two principal components, by Varimax rotation method and Kaiser normalization. Cumulative \% of variance amounts to $86 \%$. First component $(63 \%$ of variance) is associated to "trophically available metals" (TAM) and the second one $(23 \%$ of variance) to the mussels age.

\begin{tabular}{|ccc|}
\hline & \multicolumn{2}{c|}{ Correlation coefficients } \\
& Component 1 & Component 2 \\
\hline Cd ( $\mu$ g) & 0.62 & 0.62 \\
\hline Zn ( $\mu$ g) & 0.81 & 0.47 \\
\hline Cu ( $\mu$ g) & 0.96 & 0.17 \\
\hline Fe ( $\mu$ g) & 0.93 & 0.08 \\
\hline Mn ( $\mu$ g) & 0.84 & -0.04 \\
\hline MT (mg) & 0.89 & 0.28 \\
\hline $\begin{array}{c}\text { Digestive } \\
\text { gland mass (g) }\end{array}$ & 0.85 & 0.46 \\
\hline Shell mass (g) & 0.01 & 0.94 \\
\hline \% of variance & 63 & 23 \\
\hline $\begin{array}{c}\text { Cumulative } \\
\text { \% of variance }\end{array}$ & $\mathbf{8 6}$ \\
\hline
\end{tabular}


Figure Captions

Fig. 1 Marine coastal area of the Kaštela Bay, Eastern Adriatic Sea, and the deployment sites (A to D) for caged mussels Mytilus galloprovincialis Lmk.

Fig. 2 Temporal variation of average digestive gland mass (g) of mussels M.galloprovincialis caged over 12 months at 4 sites $\left(A=\int ; B=\left(; C=\mid ; D=\int\right)\right.$.

Fig. 3 Temporal variation of MT concentration $\left(\mathrm{mg} \mathrm{ml}^{-1}\right)$ in heat-treated cytosol (S30)

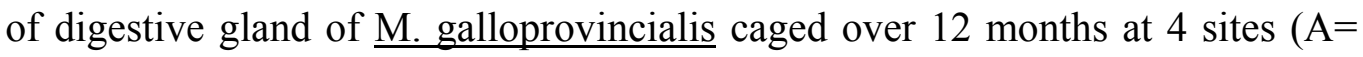
$\left(; \mathrm{B}=\left(; \mathrm{C}=\mid ; \mathrm{D}=\int\right)\right.$.

Fig. 4 Temporal variation of MT (mg) and trace metal tissue content $(\mu \mathrm{g})$ in mussels M. galloprovincialis caged over 12 months at 4 sites: a) MTs, b) Cd, c) Mn, d) $\mathrm{Cu}, \mathrm{e}) \mathrm{Zn}$ and f) Fe. Site legend: $\mathrm{A}=\int ; \mathrm{B}=\left(; \mathrm{C}=\mid ; \mathrm{D}=\int\right.$.

Fig. 5 Temporal increase of average calcareous shell mass (g) of mussels M.galloprovincialis caged over 12 months at 4 sites (A to D, Fig. 1). 


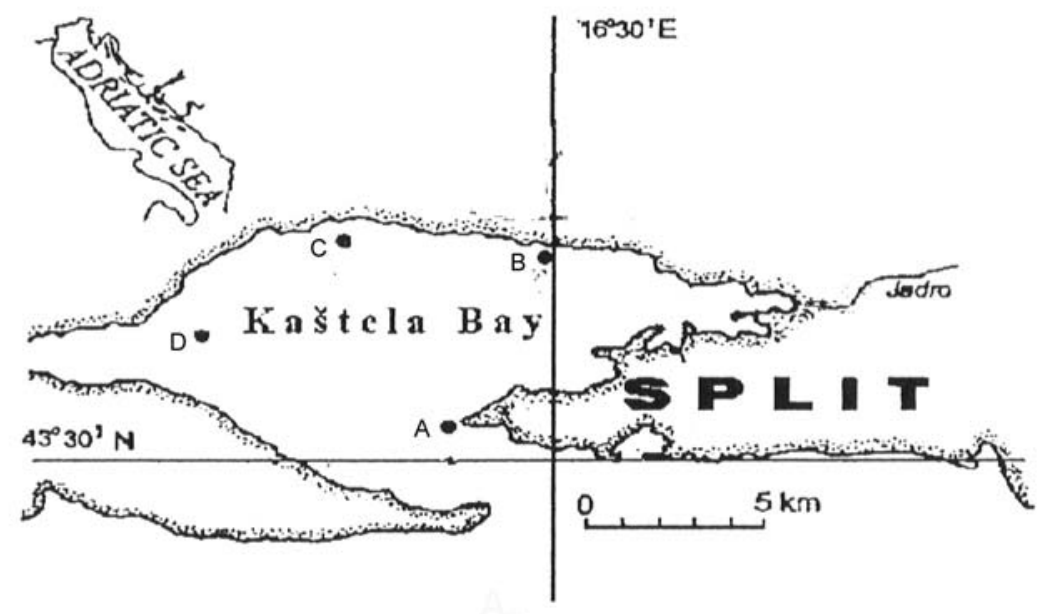




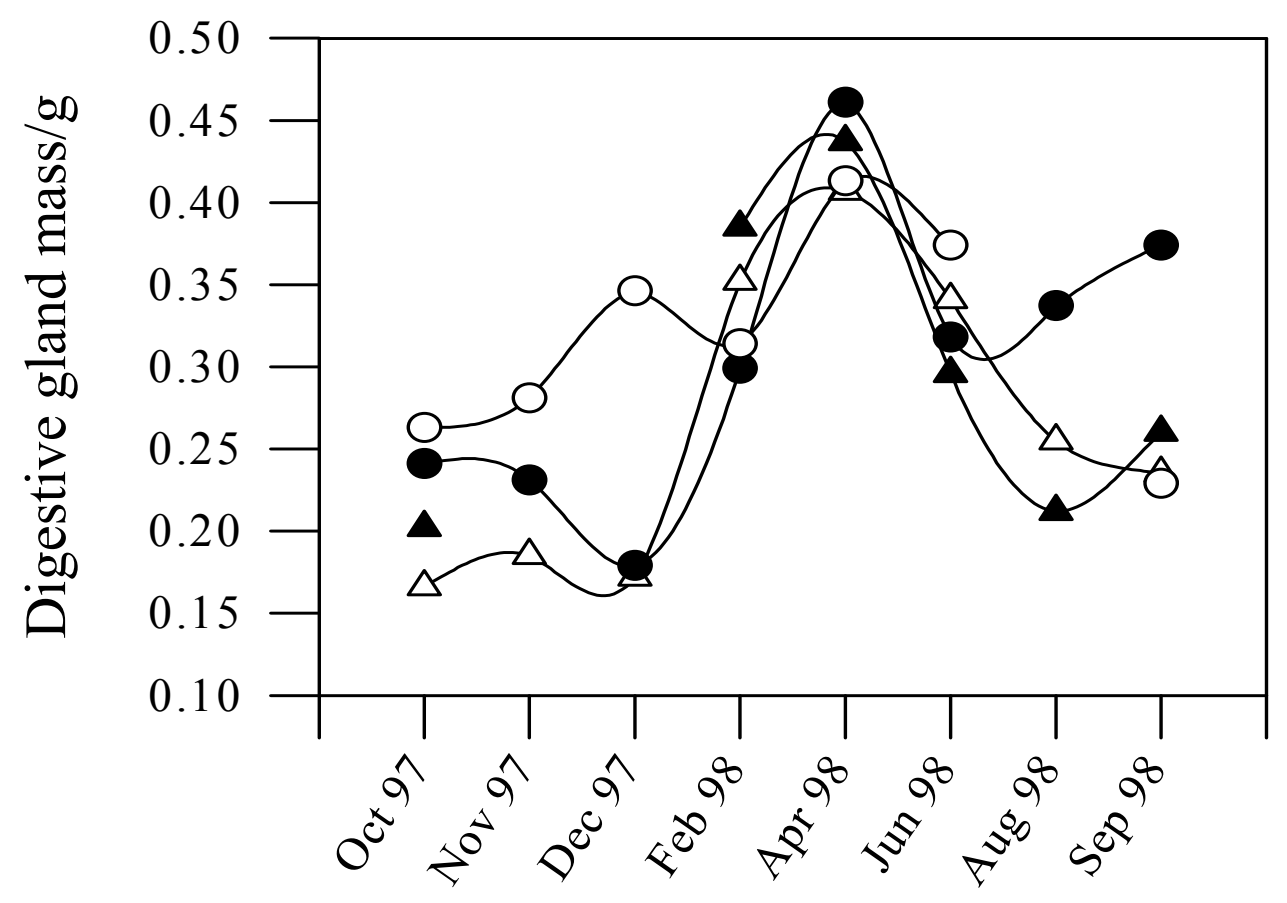




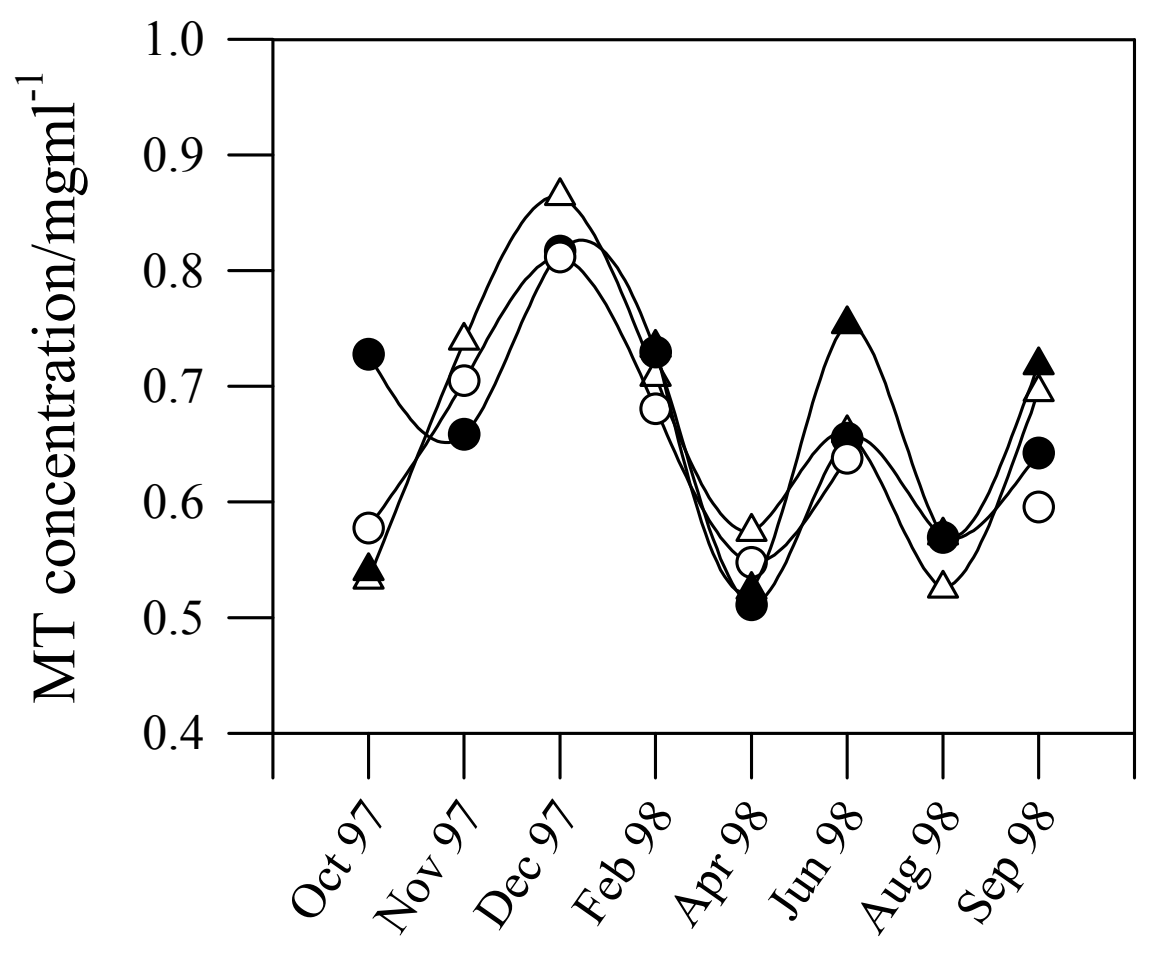



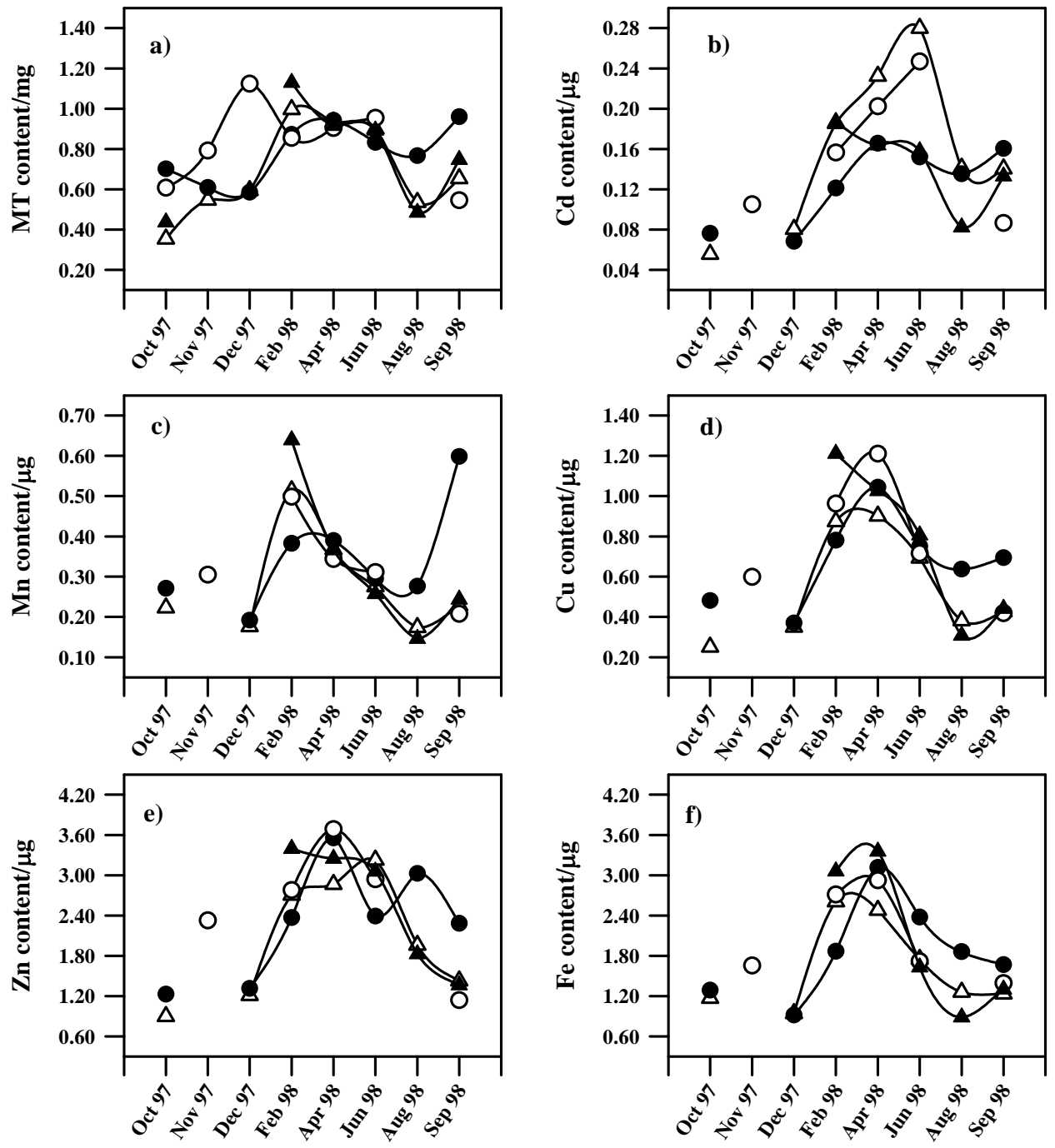


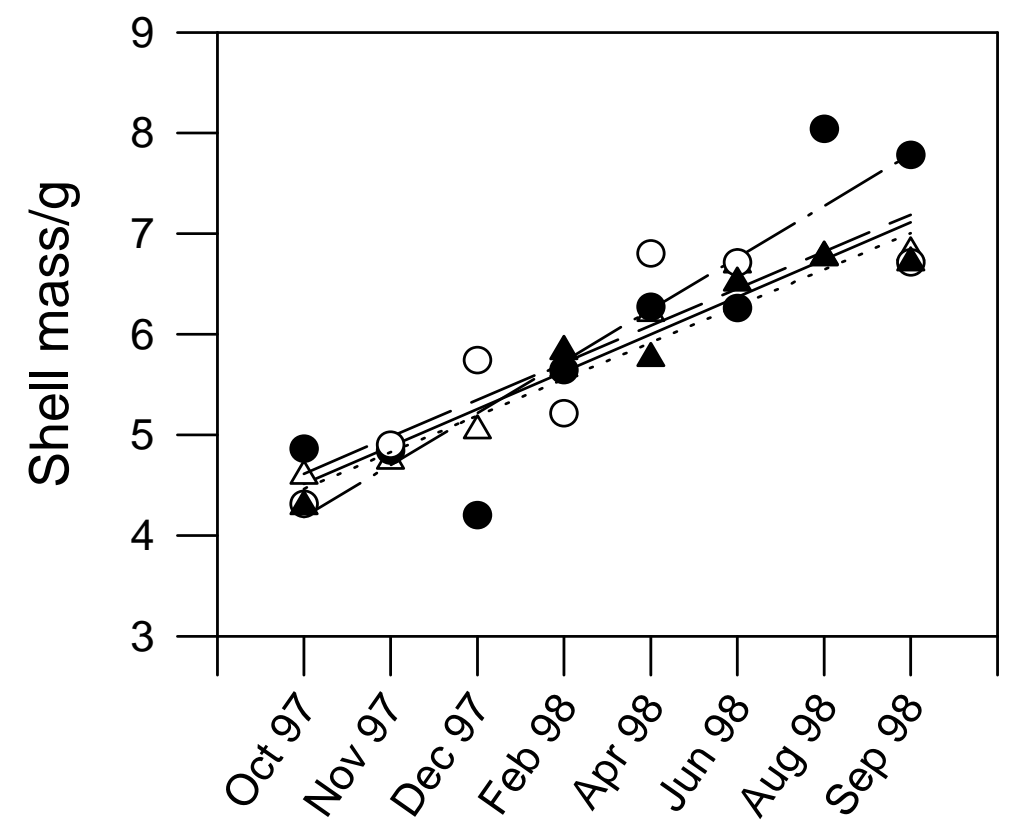

